\title{
Frederician Rococo at the Service of the German Empire: The 1900 Paris World's Fair and the Decorative Arts
}

\author{
TOBIAS LOCKER*
}

Frederician Rococo at the Service of the German Empire:
The 1900 Paris World's Fair and the Decorative Arts

Abstract

At the end of the nineteenth century the decorative sculptor Johann Melchior Kambly was rediscovered by the German art historian Paul Seidel as an artist of the Frederician Rococo. Kambly's workshop had produced, amongst other things, stately furniture with gilt bronze mounts in the eighteenth century, and after Seidel's discovery would provide the historical roots for a prestigious branch of the German Empire's contemporary artistic industry keen to catch up with its competitors, especially the French. The article shows how this argument, based on Seidel's findings, was exploited for nationalistic purposes at the 1900 World's Fair in Paris. An explanation is given of how it was used on two levels-within the context of the exhibition presented at the German Pavilion, and at the exhibition of a prestigious contemporary furniture ensemble at that World's Fair that the luxury cabinetmaker Julius Zwiener had created for the German Emperor.

\section{El Rococó del regnat de Frederic el Gran al servei de l'Imperi Alemany: L'Exposició Universal de París de 1900 I LeS arts decoratives}

\section{RESUM}

A finals del segle XIX l'historiador de l'art alemany Paul Seidel va redescobrir l'escultor i decorador Johann Melchior Kambly com a artista destacat del Rococó a la Prússia del regnat de Frederic el Gran. El taller de Kambly, que al segle XVIII havia produït entre altres objectes mobiliari senyorial amb muntures de bronze daurat, oferia, arran del descobriment de Seidel, els orígens històrics d'una de les branques més prestigioses de la indústria artística contemporània de l'Imperi Alemany, la qual volia posar-se al dia amb els seus competidors, especialment el francès. El següent article desenvolupa com aquest argument, basat en els descobriments de l'historiador de l'art alemany Paul Seidel, va ser aprofitat amb finalitats nacionalistes durant l'Exposició Universal de París de l'any 1900. S'argumentarà la seva utilització en dos nivells, en primer lloc, en el context de l'exposició presentada al Pavelló d'Alemanya, i posteriorment a través de l'exhibició d'un prestigiós conjunt de mobles contemporanis que l'ebenista Julius Zwiener havia creat per a l'emperador d'Alemany.

\footnotetext{
* This text was conceived within the framework of the research project ACAF/ART IV “Cartografías analíticas, críticas y selectivas del entorno artístico y monumental del área mediterránea en la edad moderna" (HAR2015-66579-P), funded by the Spanish Ministry of Economy and Competitiveness (Ministerio de Economía y Competitividad)
} 
LOCKER, T., "Frederician Rococo at the Service of the German Empire: The 1900 Paris World's Fair and the Decorative Arts", Acta/Artis. Estudis d'Art Modern, 4-5, 2016-2017, pp. 89-97

KeYwords: Prussia, Frederician Rococo, decorative arts, Johann Melchior Kambly, Julius Zwiener, 1900 Paris World's Fair, Nationalism

PARAules Clau: Prússia, el Rococó de Frederic el Gran, arts decoratives, Johann Melchior Kambly, Julius Zwiener, Exposició Universal de Paris de l'any 1900, Nacionalisme

In 1950, the lasting ruins of the baroque City Palace in Berlin, the so-called Stadtschloss that had been struck twice by Allied bombs in 1945 and been completely burned out, were finally blown up. ${ }^{1}$ The Communist regime of the GDR, installed in 1949 by the Soviet Union in the former Russian sector, had decided to eliminate the still-visible traces of the former seat of the Hohenzollern Dynasty, which was considered the militaristic predecessor of Nazi Germany, wanting to cleanse its capital of the powerful symbol of Prussian sovereignty. Just one balcony, from which Karl Liebknecht had declared the German Socialist Republic in 1918, was preserved and later integrated in the GDR's State Council Building that was built from 1962 to $1964 .^{2}$

In the nineteenth century, the Stadtschloss, transformed from 1699 onwards by Andreas Schlüter for the Prussian Elector Frederick III into a baroque residence, had become the stonebuilt symbol of Prussia's ascent to its royal crown in 1700. In the late nineteenth century, this "promotion" on the European stage was considered a premonition of the country's rise to power that reached its climax in 1871, when the Prussian King William was crowned German Emperor. The work of historians such as Heinrich von Treitschke (1834-1896), Johann Gustav Droysen (1808-1884) and Heinrich von Sybel (1817-1895), amongst others, would stress such a perception. ${ }^{3}$ They had helped to shape the "Borussian myth", a nationalistic legend created in the second half of the nineteenth century that eventually depicted the German unification in 1871 as inevitable and glorified Prussia as the saviour of the German Nation. ${ }^{4}$ Within these narrative(s) that focussed on the Prussian lineage, the first Prussian King Frederick I and especially his grandson, Frederick II, gained importance, the latter having achieved during the three Silesian Wars (1740-1763) the acceptance of Prussia as a major player, thereby shifting the power balance on the European continent.

Incited by the Borussian trend in historiography that nourished the myth of "Frederick the Great", nineteenth-century art historians focussed on the artistic production under his reign. ${ }^{5}$ In the last third of that century, scholars such as Paul Seidel had started to discover the particu-

\footnotetext{
1. Maether, B., Die Vernichtung des Berliner Stadtschlosses: Eine Dokumentation. Berlin: Arno Spitz, 2000.

2. Ibidem, p. $127 \mathrm{ff}$.

3. Treitschke, H. von, Deutsche Geschichte im Neunzehnten Jahrnundert, 5 vols. Leipzig: S. Hirzel, 1879-1894; DroYSEN, J.G., Geschichte der Preußen, 5 vols. Berlin: Von Veith und Co., 1855-1886; SyBEL, H. von, Die deutsche Nation und das Kaiserreich. Eine historisch-politische Abhandlung. Düsseldorf: Buddeus, 1862; for a general introduction, see DoERING-MANTEUFFEL, A., Die Deutsche Frage und das Europäische Staatensystem 1815-1871. Munich: Oldenbourg, 2001, pp. 53-59; analysing the arguments of von Treitschke in the contemporary debates is, for example, BIEFANG, A., "Der Streit um Treitschkes 'Deutsche Geschichte' 1882/83. Zur Spaltung des Nationallibealismus und der Etablierung eines national-konservativen Geschichtsbildes", Historische Zeitschrift, 262, 1996, pp. 391-422.

4. It was analysed more closely in the twentieth century and given its distinct name using the Latin name for Prussia, Borussia.

5. Two exemplary analyses regarding the epithet "the Great” are: ScHIEDER, T., Über den Beinamen 'der Große.' Reflexionen über historische Größe, Rheinisch-Westfälische Akademie der Wissenschaften, Vorträge, G 271. Opladen: Westdeutscher Verlag, 1984; KAISER, M., “Friedrichs Beiname 'der Große'. Ruhmestitel oder historische Kategorie?”, in Friederisiko. Friedrich der Große, exh. cat., 28 April - 28 October 2012, Neues Palais und Park Sanssouci, Potsdam. Munich: Hirmer, 2011, vol. 2 (Die Essays), pp. 246-261. For an analysis of Frederick II as "homme-mémoire" referring also to the creation of his nimbus of
} 
larities of Frederician interiors. ${ }^{6}$ They constituted an important sector of the Prussian artistic output of the eighteenth century, providing examples that proved Germany's cultural and artistic specificity, in a field that was at that time dominated by the French. This article will show how such findings about the production of royal interiors, bronzes and furniture under Frederick II were exploited for the arguments that were developed within the processes of nationbuilding.

During his youth as Crown Prince, Frederick II (1712-1786) had already developed a distinctive Francophilia, which he cultivated in fields such as philosophy, literature and the arts. ${ }^{7}$ In connection with various building projects, this interest would eventually evolve and manifest in the interior decorations of his residences (e.g. in Rheinsberg and in Charlottenburg), thus leading to the codification of a distinct Rococo style. As it was developed under Frederick's tutelage and would persist throughout his whole reign, it was named by nineteenth-century art historians Frederician Rococo. This style tends to be more exuberant than contemporary French Rococo creations, also referring to Dutch and Italian models. ${ }^{8}$ In its late phase it would include classicist influences-at that time en vogue in Europe-without losing the overall Rococo appearance.

Whereas today the vast majority of objects within Frederician interiors have been identified as Prussian products, it was quite a sensation in 1895 when the art historian Paul Seidel rediscovered Johann Melchior Kambly as the main manufacturer of gilt bronze mounts and state furniture, when he was working on Frederician bronze decorations. ${ }^{9}$ This artisan-artist had been forgotten for a long time and until the end of the nineteenth century his impressive pieces of state furniture had even been considered French products due to their sumptuous gilt (and sometimes silvered) bronze decoration and their high artistic and artisan quality. Actually, this discovery enabled Seidel to give the German production of bronzes and luxury furniture its own roots and, at the same time, to dismiss the historic argument of the German subjugation to French taste. Imbued with a distinct Frederician character and created by a German-speaking artist who had worked in Prussia, these historic artefacts were henceforth interpreted as specific German art objects-qualitatively comparable with eighteenth-century French ones.

Seidel's findings showed how the Swiss-born Johann Melchior Kambly had come to Potsdam and installed there in 1752 a "Fabrike of Bronze do'oré" works. Kambly would successively provide the majority of decorative metal works for the King and, amongst other things, the gilt metal decorum for an entire dining hall in Charlottenburg Palace that gave the room - the so-called salle de bronze-its name. ${ }^{10}$ He had come to Potsdam in 1743 , most probably being

greatness, see Kroll, F.-L., “Friedrich der Große”, in François, E.; Schulze, H. (eds.), Deutsche Erinnerungsorte. Munich: Beck, 2001, vol. 3, pp. 620-635.

6. SEIDEL, P., “Die Metallbildhauer Friedrichs des Großen”, Jahrbuch der preußischen Kunstsammlungen, XVI, 1895, pp. 48-6o.

7. It was expressed, for example, in his favouring French painters during his youth: BöRSCH-SuPAN, H., "Friedrich der Große als Sammler von Gemälden”, in HoHenzolleRN, J.G. von (ed.), Friedrich der Große. Sammler und Mäzen, exh. cat., 28 November 1992 - 28 February 1993, Kunsthalle der Hypo-Kulturstiftung, Munich (in collaboration with the Bayerischen Staatsgemäldesammlungen). Munich: Hirmer, 1992, pp. 96-103.

8. Eggeling, T., Raum und Ornament. Georg Wenceslaus von Knobelsdorff und das friderizianische Rokoko. Regensburg: Schnell \& Steiner, 2003; GRAF, H., "Die friderizianischen Schildpattmöbel. Vorbild, Transponierung und Innovation eines Möbeltyps am Hof Friedrichs des Großen”, in Friederisiko..., vol. 2, pp. 210-232; LocKER, T., "A Prussian factory of bronzes á la française: Johann Melchior Kambly (1718-84) and the adoption of Parisian savoir-faire", in BougRARIT, D.; BASSETT, J.; Bewer, F; Bresc-Bautier, G.; Malgouyres, P.; Scherf, G. (eds.), French Bronze Sculpture. Materials and Techniques 16th18th Century, London: Archetype, 2014, pp. 166-177.

9. SEIDEL, P., "Die Metallbildhauer...”.

10. This unique interior was destroyed during WWII. 
attracted by one of several calls to artists, artisans and entrepreneurs that the Prussian king had announced after his ascension to the throne." Three years later, his work is traceable for the first time at the site of Sanssouci Palace, where he participated as a decorative sculptor in the execution of its exterior and interior decoration. Quickly he would show off his multi-faceted talent, providing for the building, in 1747, "gilt metal work [...] sixteen capitals for columns and as many for pilasters for 9,300 thalers", and later on also providing sculpted furniture. ${ }^{12}$ In 1749 , Kambly started to produce state furniture, the first piece being a cabinet consisting of a cartonnier with bas d'armoire copied after a French model. ${ }^{13}$ In contrast to this copy of a French design, Kambly's subsequent output displayed the specific Frederician style. ${ }^{14}$ The design of these pieces of royal furniture is heavier than those of Parisian luxury furniture and, in most cases, a reddish tortoiseshell underlay provides the perfect background for the gilt or sometimes silvered bronze mounts. ${ }^{15} \mathrm{~A}$ significant number of these Frederician objects have been preserved and are today visible in various palaces and pavilions situated in Sanssouci Park in Potsdam. ${ }^{16}$

At the end of the nineteenth century, some of these prestigious objects were used by the German Emperor William II (1859-1941) and his wife in their private quarters on the first floor of the New Palace. They had been integrated in the redecorated apartments that reflected the bourgeois taste of the nineteenth century to a certain extent, seeming rather crowded and less stately in comparison to eighteenth-century furnishings. ${ }^{17}$ Another collection of Kambly's objects was kept in the original royal apartments of Frederick II. ${ }^{18}$ These rooms had not been remodelled, in great reverence to the Emperor's illustrious ancestor. Before the invention of the period room, they served as a kind of museum showroom that could convey the aura of the eighteenth century, presenting the authentic site of Frederick's activity, the founding father of Prussia's greatness.

With Paul Seidel's identification of these interiors as distinctive Prussian art objects-not copies after French models-an opportunity to reinforce a specific German tradition opened up that could become useful in the ongoing construction of German nationhood. In his article, the art historian would not just stress the equality of the eighteenth-century Prussian art production in a field that was generally considered the strength of the French; in light of a growing

11. Geheimes Preussisches Staatsarchiv Preussischer Kulturbesitz Berlin Dahlem (GStAPK), I. HA, Rep. 96B, No. 136, fol. 506r; on 27 July 1740 a "Patent that all valuable and skillful people coming from foreign countries and settling in Berlin, will receive besides all already mentioned benefits also the exemption from taxes and services (regarding the quartering of military) for two years [...]" was decreed and published in the newspaper Berlinische Nachrichten von Staats- und gelehrten Sachen, Thursday, 18 August 1740, as well as in the Berlinische Privilegierte Zeitung, on 1 September 1740; see also: MANGER, H.L., Baugeschichte von Potsdam, besonders unter der Regierung König Friedrichs des Zweiten. Berlin-Szczecin: Nicolai, 1789, vol. 1, p. 65.

12. MANGer, H.L., Baugeschichte von Potsdam..., vol. 1, p. 76.

13. For an in-depth study of the writing desk that also includes these complementary pieces, see SCHICK, A., Der französische Schreibtisch Friedrichs des Großen im Schloss Sanssouci in Potsdam. Berlin-Potsdam: SPSG, 2008.

14. Paul Seidel had already noticed this detail when he discovered Kambly as the creator of this piece (SEIDEL, P., "Die Metallbildhauer..., p. 57).

15. Just two pieces have a veneer in cedar. Recently, it was discovered that a lot of the parts that have been considered cedar are in fact juniper. An analysis of the wood is given in GoTTMAnN, P., Vergleichende Untersuchungen an zwei Standuhren von Johann Melchior Kambly, thesis on "conservation and restoration of wooden objects". Faculty of Architecture and Town planning, Fachhochschule Potsdam, 2011, p. 62 and protocol of wood identification in the appendix; regarding the same subject, see also WeBER, J., "Zeder? Nein, Wacholder! Quellenstudien und Holzartenbestimmungen an Innenausstattungen Potsdamer Schlösser", in Michaelsen, H. (ed.), Königliches Parkett in Preußischen Schlössern. Geschichte, Erhaltung und Restaurierung begehbarer Kunstwerke. Petersberg: Imhof, 2010, pp. 391-404.

16. They are managed by the foundation Stiftung Preussische Schlösser und Gärten Berlin-Brandenburg (SPSG).

17. This is reflected by the entries in the $1895 / 96$ inventories of the New Palace referring to the Emperor's apartments on the first floor of the New Palace (Plankammer, Neues Palais, SPSG, Hist. Inventare, No. 719-722), as well as photos taken of the imperial apartments in the early twentieth century, today conserved at the Messbildarchiv Brandenburgisches Landesamt für Denkmalpflege Zossen/Wünsdorf (e.g. negative nos. 1625.62 or 1625.83).

18. See entries referring to the Royal Apartment on the ground floor in SPSG, Hist. Inventare, No. 719-722. 
art industry, increasing numbers of applied arts museums and craft schools as well as the growing importance of World Exhibitions at the end of the nineteenth century, he saw in Kambly's work a precursor of the German contemporary bronze production. He emphasized this point, finishing his article with the statement that Berlin could provide in 1895 "in this area-without doubt-everything, which until now just could be found in Paris.".9

In order to understand the contemporary dimension of this quote, one has to consider two things. Firstly, in the eighteenth century, Paris was a fashion metropolis that set the tone for large parts of Europe.$^{20}$ Aristocrats would visit the capital on their Grand Tour, send artists to the city in order to form their taste and commission agents or envoys to buy fashionable items there. ${ }^{21}$ In this way, the European nobility was able to recreate the representative gôut français outside of France. Considering this context, thanks to Paul Seidel's work, Prussia's contemporary production of bronzes gained its own domestic roots that could stand up to comparison with the French luxury products of the eighteenth century. Secondly, the sector of luxury furniture, with its ostentatious use of bronze mounts, was still a strength of the French in the nineteenth century. Especially within the prestigious style of the Neo-Rococo, extraordinary objects emerged from the Parisian industry. A good example is the case of (Joseph-) Emmanuel Zwiener, who established his business in Paris and had been awarded a gold medal for a prestigious cabinet on stands at the World's Fair in $1889 .^{22}$

Such luxurious and ostentatious objects were highly regarded by the financial and aristocratic elites all over the world and even the German Emperor had bought furniture from Zwiener in 1889 via his intermediary - the art historian Paul Seidel. ${ }^{23}$ This first contact with the German Empire was actually just the beginning of an intensified relation with the Zwiener family that would result in Emmanuel's younger brother Julius coming to Berlin and opening a workshop there in $1895 .{ }^{24}$ Although it is not entirely clear what might have triggered Julius' translocation, Seidel's article about the discovery of Kambly, published the same year, might shed some light on the reasons.

With Seidel's statement that Berlin could provide everything that until then could only be found in Paris, the creation of Julius Zwiener's enterprise in Berlin gains a distinct twist. Firstly, he was directly related to his famous brother Emmanuel, who ranked (with François Linke, Emmanuel Alfred Beurdeley and Henry Dasson) amongst the leading Parisian furniture makers at the end of the nineteenth century. Furthermore he had "worked several years for his brother in Paris, learned the art of chiselling and how to treat fire-gilt bronze mounts".5 He thus had learned from one of the best and when the chance opened up to become inde-

19. SEIDEL, P., “Die Metallbildhauer..., p. 60.

20. Bremer-David, C. (ed.), Paris: Life and Luxury in the Eighteenth Century, 26 April - 7 August 2011, J. Paul Getty Museum at the Getty Center, Los Angeles. Los Angeles: Getty Publications, 2011.

21. See, for example, Hartmann, P.C., "Luxuseinkäufe des Münchener Hofes in Paris (1718-1727)", Francia, I, 1973, pp. 350-360.

22. Balmont, J., "Le mobilier a l'exposition", in Revue de l'Exposition universelle de 1889, vol. 2, p. 331; see also an engraving by Kreutzenberger "Meuble à bijoux de style Louis XV (compose et execute par M. Zwiener)", in Revue de l'Exposition universelle de 1889, vol. 2, p. 336; PAYNE, C., François Linke, 1855-1946. The Belle Epoque of French Furniture. Woodbridge: Antique Collectors Club, 2003, pp. 71-74; Denise Ledoux-Lebard mentions "Joseph" as his first name, but Jörg Meiner argues convincingly in his recent study about the brother of the furniture maker Julius Zwiener that the name was actually never used, mentioning that his furniture was just stamped "E. Zwiener" - therefore he will be referred to in this article as Emmanuel Zwiener: LEDOuX-LEBARD, D., Le Mobilier français du XIXe siècle 1795-1889. Paris: Les éditions de l'amateur, 2000, p. 645; MeIner, J., Berliner Belle Époque. Der Ebenist Julius Zwiener und die Kunstmöbel für den Hof Kaiser Wilhelms II (1888-1918). Petersberg: Imhof, 2014, pp. 30-31.

23. GStAPK, BPH, Rep. 192, NI Seidel No. 74, fol. 31-33.

24. For further information about the Zwiener workshop see: MeINER, J., Berliner Belle Époque...; very enlightening regarding the relation of the Zwiener brothers and their two workshops (Emmanuel's in Paris and Julius' in Berlin): p. 3off.

25. Archival document quoted in: MeIner, J., Berliner Belle Époque..., p. 31. 
pendent he took it. ${ }^{26}$ Secondly, it is very likely that his decision to leave the French capital was motivated by certain financial promises from the Germans, who thereby facilitated a knowhow transfer that gave their own artistic industry a decisive push. As William II was an important patron of the arts in the German Empire with significant financial resources, working close to the imperial German court certainly promised important commissions and prestige. Thirdly, Zwiener was born in Silesia, which was part of the German Empire, and thus of German roots. Therefore, he and his products could be easily integrated into the nation-shaping narrative of Germany.

Whereas the link to Kambly provided the German bronze and luxury furniture industry with historic roots, with Julius Zwiener coming to Berlin the prestigious production of high-end furniture had found a worthy heir. The furniture maker, brother of the famous Emmanuel Zwiener, added with his name (and his know-how) the glamour that the German bronze and luxury furniture industry needed in order to be more competitive-especially with respect to French products. The fact that Seidel became director of the prestigious Hohenzollern-Museum in Berlin in 1896 might, to a certain extent, even be interpreted as an acknowledgement of his services for having participated in convincing Julius to come to Berlin. ${ }^{27}$

In fact, it seems that Julius Zwiener's relocation would become part of a larger propaganda campaign, when William II commissioned of the luxury cabinetmaker a very prestigious bedroom suite. ${ }^{28}$ This ensemble consisted of a bed with cupboards and bedside tables, which were decorated with exquisite floral images executed in veneer and embellished with gilt bronze mounts. The entire suite would be put to the service of the state and was shipped to the 1900 World's Fair in Paris and exhibited in room XIII of the group XII (Decoration and Interiors of public buildings and residential premises) at the Esplanade des Invalides. ${ }^{29}$ It proved the outstanding quality of the Imperial production of high-end furniture at the industrial competition between the different nations, and won a prestigious prize. The following year, Seidel-who had been involved in the organization of the German contribution at that World's Fair-published a propagandistic booklet with the title "For his Majesty the German Emperor created Art-Furniture and Bronzes at the Paris World Exhibition 1900".30 The booklet explained the huge success of German artistic products to the German readership, featuring seventeen full-page illustrations and eleven text images and showing various items produced by Julius Zwiener, amongst others. However, above all, the text connected the contemporary decorative arts industry to "German" historic production in that field, presenting Kambly's work as the foundations of an independent and decisively Prussian tradition of bronzes and luxury furniture making. Adding to this argument and underlining the stylistic independence from French historic models, Seidel did not forget to highlight the "particular style of Potsdam", and he wrote that the Frederician Rococo "can be easily distinguished from any similar achievements in Germany or France". ${ }^{11}$

The same argument was presented in the most important section of the German pavilion, but with a more conciliatory strategy. Built in the style of the early German Renaissance, it had

26. His brother Emmanuel would sell his business in 1895 to Jean-Henri Jansen. He stayed in Paris and both became business partners. Besides he would also help his younger brother in Berlin financially; MeInER, J., Berliner Belle Époque..., p. 31 .

27. The museum was founded in 1877 by the art historian Robert Dohme in the former Baroque palace Monbijou. After Dohme's death, Seidel became his successor. For further information about the now-destroyed palace and its museum, see the official website: http://monbijou.etielle.de/geschichte2.html (accessed 5 August 2014).

28. BAER, W., Eine Schlafzimmer-Ausstattung von Julius Zwiener. Ein Auftrag Kaiser Wilhelms II. für das Berliner Schloss, 1895-1900, Patrimonia 13. Berlin: Kulturstiftung der Länder und der Verwaltung der Staatlichen Schlösser und Gärten Berlin (SPSG), 1989.

29. Witt, O.N. (ed.), Weltausstellung in Paris 19oo. Amtlicher Katalog der Ausstellung des Deutschen Reichs, exh. cat., 15 April - 12 November 1900, Paris. Berlin: Selbstverlag des Reichskommissariats, 1900, p. 327 [cat. 3866 ].

30. SEIDEL, P., Für Seine Majestät den Deutschen Kaiser angefertigte Kunstmöbel und Bronzen aufder Pariser Weltausstellung 190o. Leipzig-Berlin: Giesecke \& Devrient, 1901.

31. Ibidem, p. 10. 
been constructed just for the 1900 World's Fair on the banks of the Seine, providing a showcase for a photographic exhibition, the German book trade and wine industry, and including a wine restaurant..$^{32}$ However, its main attraction was an exhibition of the French art collections of Frederick II. ${ }^{33}$ At first glance, this show featured French Baroque and Rococo art, certainly with the intention of keeping any animosities that had existed since the Germans had defeated the French in 1871 during the Franco-Prussian war to a minimum. Nevertheless, they were presented in a setting that recreated the interiors in which Frederick II had lived and worked. Hence, one could surmise that the French art was used as a Trojan horse to also present the interiors of the forefather of Prussia's greatness. This way the exhibits were not just provided with a historic shell, but the latter also gave reason to put forward the previously mentioned argument. ${ }^{34}$

The German pavilion was a huge success and, for example, the Frenchman Émile Berr praised the historic exhibition. ${ }^{35}$ Nevertheless, he would not follow the argument that the German production of luxury furniture had its own roots. Although Seidel had stressed in the official catalogue the distinctiveness of the Frederician interiors, emphasizing on the basis of his recent research that almost no Frenchmen had helped, Berr did not "buy" the line of argument that declared the artistic independence of Prussian interiors. Instead, he wrote, "all the elements of this decoration are borrowed from French art, Frederick had the furniture made after French models under the direction of French workers" ${ }^{36}$ These words clearly show that Seidel's argument of using the showcasing with its historic interiors to prove the (historic) distinctiveness of German artistic production seems to have been acknowledged by the Germans themselves but not by the main target of the exhibition, the French public. Of course, this is not such a big surprise, as the confidence of the latter regarding the historically acknowledged predominance of its own nation in that field was supported by the French press, as Berr's article exemplifies.

Elements of contemporary Prussian luxury furniture at the World's Fair in Paris-especially Zwiener's bedroom suite-could in fact be understood as the contemporary part of the argument that was put forward at the German Pavilion. In the previously mentioned booklet, Seidel retrospectively emphasized the success of the Imperial Art-Furniture and Bronzes at the Paris World Exhibition 1900, stressing, as in his contribution to the official catalogue, the independence of the Prussian industry. ${ }^{37}$ Nevertheless, whereas Zwiener's bedroom suite was quite elaborately referred to in this publication, the French did not take much notice of its success. The latter would rather focus its appraisal on the Frenchman François Linke, who had produced an exceptional clock that won renown, even though the Rapport du Jury International of 1900 mentions both Zwiener and Linke as winners of a gold medal.$^{38}$ Hence, if one sees the aspects of the art exhibition in the German Pavilion and the exhibition of Zwiener's furniture as parts of a strategy that mixed historic and historicizing furniture with (art-)historical arguments as explained here, one can clearly say that it only succeeded in part. Although the French public could not be convinced, this strategy helped to increase the prestige of an important component of artistic production within German self-perception.

32. WitT, O.N. (ed.), Weltausstellung in Paris 190o..., pp. 58-121.

33. SEIDEL, P., "Die Sammlungen Friedrichs des Grossen, ausgestellt auf Allerhöchsten Befehl Seiner Majestät des Deutschen Kaisers", in WitT, O.N. (ed.), Weltausstellung in Paris 190o..., pp. 61-65.

34. SEIDEL, P., "Die Sammlungen Friedrichs..., pp. 61-65.

35. Berr, É., "Une idée du Guillaume II", in L'Exposition de Paris 190o, exh. cat., 15 April - 12 November, Paris. Paris: Montgredien, 1900, vol. 2, pp. 175-176.

36. Ibidem, p. 176.

37. SEIDEL, P., Für Seine Majestät..., title page, pp. 5, 6, 9, 10.

38. Dambreuse, C., "L’Art Industriel à l'Exposition de Meuble de Style - M.F. Linke", Revue Artistique \& Industrielle, JulyAugust, 1900; PAYNE, C., François Linke..., pp. 131 (pl. 142), 175. 
This article has argued that the rediscovery of Johann Melchior Kambly as a Frederician artist of eighteenth-century Prussian interiors and, especially, Kambly's furniture and bronzes did not only have repercussions in art history. It has shown how they were instrumentalized for nationalistic aims at the end of the nineteenth century and the beginning of the twentieth century. The text has also emphasized that this strategy only worked in part. Whereas in the German Empire Kambly's rediscovery was used to argue in accordance with the narrative of the dominant Borussian historiography, and was therefore quite easily accepted, the French would not follow this line of argument. This attempt to compete as equals in a field that had long since been a strength of the French was noticed but neglected, even though Seidel tried to stress it in the official catalogue of the German contribution to the Paris World's Fair.

The attempt outlined here to exploit an artistic language combined with a historical argument in order to back up contemporary discourses is, of course, nothing new when looking at modern history. For example, in the twentieth century, the dictatorial regime of Hitler's Germany, in its attempt to create the Third Reich, recalled the Holy Roman Empire (the 2nd Empire, that had ended with William II's abdication after World War I) as well as the Roman Empire using imperial imagery and referring in large parts to a constructed past. ${ }^{39}$ Similar procedures are also to be found in other national contexts; for example, Franco's dictatorship emphasized, especially in its beginnings, the idea of the once-great Habsburg Empire and tried to revive artistic and conceptual formulas from the past. ${ }^{40}$ However, such strategies do not just seem fit for dictatorships-present democratic states are not immune to the semantic seduction the past can provide.

For instance, the Stadtschloss mentioned in the introduction of this text provides a good example of the seductive force that the Hohenzollern Dynasty and its art patronage still exert on current politics. Even though it vanished a long time ago and was replaced from 1973 to 1976 by the "Palace of the Republic", on 17 April 2002 the Parliament of the reunited Germany eventually decided to rebuild the Baroque town palace. ${ }^{41}$ The people's palace, built by the GDR's "SED-regime" (Socialist Unity Party of Germany), had to make space for this new building, which is currently being erected. The foundation stone of this "Humboldt-Forum" baptised venture was laid on 12 June $2013 .{ }^{42}$ The projected building will show three reconstructed façades of Andreas Schlüter's palace. Furthermore, it will incorporate the historic balcony that had been integrated in the State Council Building and it will be-as the name "Humboldt-Forum" indicates-dedicated to culture and education; home to museums, archives, a library and a cultural centre. Various concepts were discussed regarding its use and the one chosen seemed to be the most suited to deactivating the political meaning and connotations of the building to a large extent. With it-so they hope-the historic shell will be filled with new meaning that emphasizes the peaceful and knowledge-driven character of the German nation in the twentyfirst century.

39. ThIEss, J., Hitler's Plans for Global Domination: Nazi Architecture and Ultimate War Aims. Oxford: Berghahn Books, 2012 (translation of the German book Architekt der Weltherschaft. Die “Endziele” Hitlers, 1976), pp. 61-99; see also SpOTTs, F., Hitler and the Power of Aesthetics. Woodstock: Overlook, 2009, pp. 311-385; MicHaUd, E., The Cult of Art in Nazi Germany. Stanford: Stanford University Press, 1996.

40. Locker, T., "The Baroque in the Construction of a National Culture in Francoist Spain: An Introduction", Bulletin of Spanish Studies, XCI, 5, 2014, pp. 657-671.

41. For a short overview of the evolution of the Hohenzollern Palace to the so-called Palace of the (Socialist-Democratic) Republic, see Jordan, K., "Vom Hohenzollernschloss zum Volkspalast. Ein kurzer Abriss zur Geschichte des Schlossplazes", in Schug, A., Palast der Republik. Politischer Diskurs und private Erinnerung. Berlin: Berliner Wissenchafts-Verlag, 2007, pp. 20-29.

42. For more information on the whole project and the ongoing construction, see the website of the Berlin Palace Humboldtforum Foundation, which is the commissioning body for the building of the Humboldt Forum: http://www.sbs. humboldforum.de/en/Home (accessed 15 August 2014). 
Be that as it may, in light of the title of the seminar, "Identity, Power and Representation: Nationalisms in Art" (at which this text was presented for the first time in a different form), and regarding that building's history, one might wonder if a re-semanticization of such a powerful symbol will be successful-especially at a time of rising tensions between European partners and with Germany being a major player in transforming the balance of power across the European Union. 